\title{
はく離·再付着流れでの血栓形成について \\ Instructions for Preparation of Manuscripts
}

\author{
○玉川雅章1，前田暁 1 \\ 1. 九州工業大学 \\ OMasaaki TAMAGAWA $^{1}$ and Akira MAEDA ${ }^{1}$ \\ 1. Kyushu Institute of Technology
}

\section{1. 緒言}

近年，遠心血液ポンプをはじめとする人工臓器の開発が盛 んに行われているが，その開発において血栓が大きな問題と なっており, 医用流体機器の代表である人工臟器やステント の開発にあたり血栓形成の工学的な予測法の確立が急務とな っている.そこで, 本研究では単純な流れ場形状であるバッ クステップ流れを用いて血栓の予測法の開発を行ってきた.

これまでに著者らは，流れ場のせん断速度と壁の材質による 吸着を考慮した血栓形成予測として，格子ボルツマン法 (LBM) ${ }^{(1)}$ を用い, 単相流におけるバックステップ流れの解析を 行い, 計算精度が差分法と同程度であることを示し(2), さら には, 界面張力のメカ二ズムを考慮した格子ボルツマン法を 用い，物体同士の界面張力による血小板や血球成分の凝集， 各相の挙動を解析してきた。 これらの計算モデルにおける凝 集や固着のパラメータを同定する必要がある.

本研究では，これらの数值計算予測法におけるパラメータ同定 のため, 血栓の可視化実験の確立を目的とする.

\section{2. 血栓の可視化実験}

\section{1 実験装置と回路}

回路内にはオリフィス管(アクリル製), 流量計, ローラーポンプ, 温度計, ポートからなり, 回路内の長さは $5[\mathrm{~m}]$ である. オリフィス 管は, 管直径 $\mathrm{D}=22[\mathrm{~mm}]$, 収縮部直径 $\mathrm{d}=8[\mathrm{~mm}]$ である. 光源 には，スペクトラフィジックス社製水泠 Ar イオンレーザー Stabilite2017(出力:2[W], 波長:514.5[m])を用い, シリンドリカ ルレンズにてレーザーシー光を(シート厚さ: $1 \mathrm{~mm}) を$ 作り, オリフィ ス管中心軸に照射する.

ヘパリンで凝固を抑えた血漿水で回路内を満たし，血栓形成 過程を 2 次元的に観察する. 血漿水の抗凝固能を戻すために, 回路内のポートよりへパリンの中和剤である硫酸プロタミンを注入 する．撮影はオリフィス管上部より，日本ローパー製の高速度 CCD カメラ MotionPro HS- 4 を用いて行う。流量は $5[1 / \mathrm{min}]$ と する.

\section{2 壁面コーティングの影響}

本報では，特に壁面吸着力の影響を調心゙るために，アクリ ル表面上に親水性コーティングを行い，血栓吸着力の影響を 調べる.コーティングはオリフィスより後方の円管内面のみ に行った．このコーティングより期待できることは，アクリ ル表面の場合は，血小板粒子が固着しにくかったものが，親 水性コーティングを行うことで，血小板の固着を起きやすく することである。これらを総合すれば，物理的には壁面固着 力を増加させたことに相当すると考えられる.

\section{3. 結果とまとめ}

また, Fig.2 はオリフィスの形状 $\mathrm{AB}$ において, 実験により得ら れた白黒のデジタル画像を濃度值に変化し, 画像化したものであ る.この図は濃度値が血漿タンパクの析出の程度を示している. 場所としては, 再付着点に強い固着を興していることが明らかに わかる.この結果と過去の結果 ${ }^{(2)}$ と比較すると, 壁面固着力が 弱い場合には，せん断忘力による凝集の効果の方が大きいこと がわかる.
これらの結果から, 壁面コーティングを行うことで壁面の固着力 が強い場合には, 血栓の固着の位置が顕著に表れ, 再付着点近 傍であることがわかり，弱い場合には，凝集の発生箇所が広籁囲 であることがわかった。

今後は,この壁面吸着力の変化とこれまでのCFDを用いた血 栓予測法の結果を比較して, 吸着力および凝集力のパラメータ 同定を行う予定である.

4. 参考文献

(1) Guy.R.McNamara and Gianluigi Zanetti:Use of Boltzmann Equation to Simulate Lattice-Gas Automata. Physical Review Letters, 61 (1988), pp.2332-2335

(2) Masaaki TAMAGAWA, CFD Study of Thrombus Formation on Shear Blood Flows by using Modified Lattice Boltzmann Method and Thrombus Observation, Proc. of ASME SBC 2008

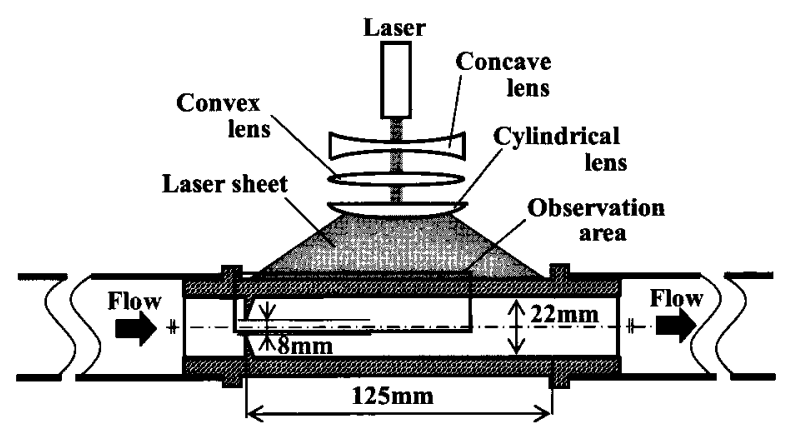

Fig. 1 Experimental apparatus for visualization of the thrombus formation in plasma flow
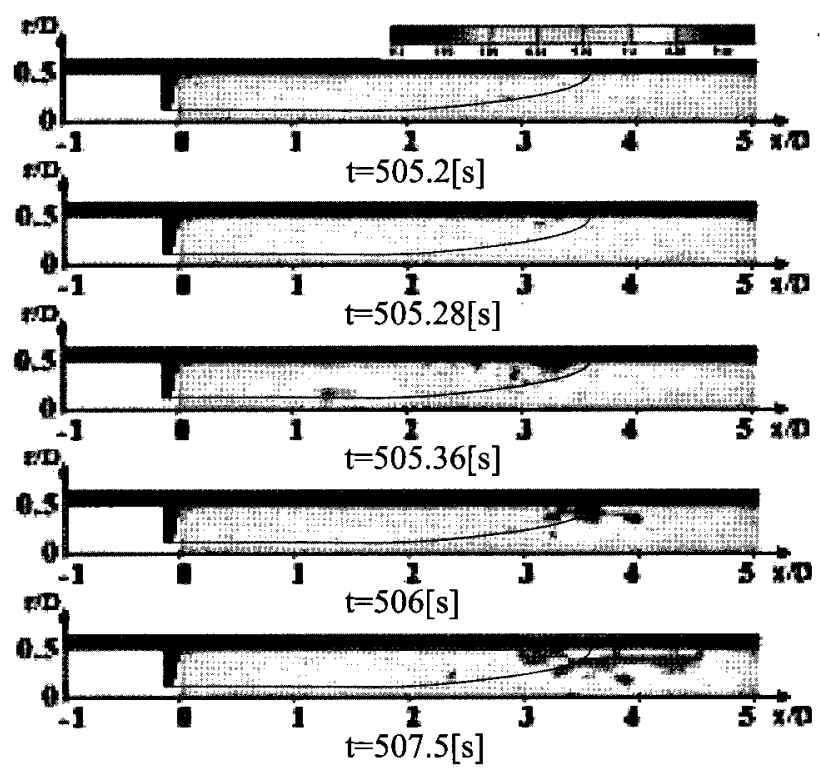

Fig.2 Continuous image of brightness contour in the orifice area 